\title{
Moderate sodium restriction with angiotensin converting enzyme inhibitor in essential hypertension: a double blind study
}

\author{
GRAHAM A MACGREGOR, NIRMALA D MARKANDU, DONALD R J SINGER, \\ FRANCESCO P CAPPUCCIO, ANGELA C SHORE, GIUSEPPE A SAGNELLA
}

\begin{abstract}
Fifteen unselected patients who had essential hypertension and whose average supine blood pressure when they were not receiving any treatment and their usual sodium intake was $162 /$ $107 \mathrm{~mm} \mathrm{Hg}$ were treated with captopril $50 \mathrm{mg}$ twice daily. After one month's treatment their supine blood pressure had decreased to $149 / 94 \mathrm{~mm} \mathrm{Hg}$. They were then instructed to reduce their sodium intake to about $80 \mathrm{mmol}(\mathrm{mEq}) /$ day. After two weeks of moderate sodium restriction they were entered into a double blind randomised crossover study comparing the effect of $\mathbf{1 0}$ Slow Sodium tablets (100 mmol sodium chloride) with matching placebo tablets while continuing to take captopril and restrict sodium in their diet. After one month of taking placebo their mean supine blood pressure was $137 / 88 \mathrm{~mm} \mathrm{Hg}$ with a urinary sodium excretion of $83 \mathrm{mmol} / 24 \mathrm{~h}$, while after one month of taking Slow Sodium tablets their mean supine blood pressure was $150 / 97 \mathrm{~mm} \mathrm{Hg}(p<0.001)$ with a sodium excretion of $183 \mathrm{mmol} / 24$ h. The mean supine blood pressure during moderate sodium restriction therefore decreased by $9 \%$ and correlated significantly with the reduction in urinary sodium excretion.

These results suggest that the combination of treatment with a moderate but practical reduction in sodium intake and an angiotensin converting enzyme inhibitor is effective in decreasing the blood pressure in patients with essential hypertension. This combined approach overcomes some of the objections that have been made to salt restriction alone and to converting enzyme inhibitors alone.
\end{abstract}

\footnotetext{
Blood Pressure Unit, Department of Medicine, Charing Cross and Westminster Medical School, London W6 8RF

GRAHAM A MACGREGOR, MA, FRCP, Wellcome senior lecturer

NIRMALA D MARKANDU, SRN, research assistant

DONALD R J SINGER, BMEDBIOL, MRCP, British Heart Foundation junior research fellow

FRANCESCO P CAPPUCCIO, MD, research fellow

ANGELA C SHORE, PHD, research assistant

GIUSEPPE A SAGNELLA, PHD, senior biochemist Correspondence to: Dr MacGregor.
}

\section{Introduction}

The effectiveness of moderate sodium restriction alone in decreasing blood pressure in patients with mild to moderate essential hypertension is controversial,' owing at least partly to the finding that the decrease in blood pressure under such conditions is related to the severity of hypertension. Thus patients with borderline or mild hypertension may show no or only a small decrease in blood pressure. ${ }^{2}$ This differing response seems to be related to a blunting of renin responsiveness to sodium restriction as high blood pressure becomes more severe. ${ }^{34}$ In other words patients showing the smallest decrease in blood pressure had the greatest increase in renin concentrations, which offset the decrease in blood pressure, and angiotensin II.

The angiotensin converting enzyme inhibitors block the enzyme responsible for the conversion of angiotensin I to angiotensin II. ${ }^{6}$ This leads to a decrease in angiotensin II production and thereby a decrease in blood pressure. ${ }^{7}$ In many patients who have untreated essential hypertension and whose sodium intake is normal, however, renin and angiotensin II are below normal and the decrease in blood pressure that occurs with converting enzyme inhibition is less than that in patients with higher renin activity. ${ }^{89}$

Theoretically then the combination of moderate sodium restriction and an angiotensin enzyme inhibitor should overcome the disadvantages of both treatments given alone. We therefore conducted a study of moderate sodium restriction in patients who had mild to moderate essential hypertension and who were already being treated with captopril. The alteration in the diet was performed in a double blind manner by using Slow Sodium tablets and matching placebo.

\section{Patients and methods}

Patients were referred by local general practitioners to the blood pressure unit. We had observed those participating in the trial for several months before entry to the trial. No underlying cause for their high blood pressure had been found, and supine diastolic blood pressure was greater than $95 \mathrm{~mm}$ $\mathrm{Hg}$. Patients who had renal failure, ischaemic heart disease, or cerebrovascular disease, or who were taking oral contraceptives or any other drug, were excluded from the study. Informed consent was obtained from each 
patient. Fifteen patients (mean age 52 (range 33-71)) were entered in the study and all 15 completed it; they comprised 11 men and four women, and 10 were white and five were black. Their mean blood pressure after one month of no treatment before being given captopril was $162 / 107 \mathrm{~mm} \mathrm{Hg}$.

After an observation period of at least one month during which they received no treatment patients started treatment with captopril $50 \mathrm{mg}$ twice daily for one month. At the end of this month of treatment patients and their spouses, or whoever did the cooking in the household, were instructed by the metabolic ward dietitian on how to reduce their sodium intake to about 70 to $80 \mathrm{mmol}(\mathrm{mEq}) /$ day. No attempt was made to alter potassium intake. Sodium intake was reduced by not adding salt either at the table or during cooking and avoiding foods known to be loaded with sodium. Brief, clear instruction sheets were also given to the patients, and at each visit the nurses in the blood pressure unit reinforced the dietitian's instructions. Patients were seen after two weeks of moderate sodium restriction and were then entered into a double blind randomised crossover study comparing one month's treatment with 10 Slow Sodium (CIBA) tablets a day (one tablet contains $10 \mathrm{mmol}$ sodium chloride) with one month's treatment with 10 Slow Sodium matching placebos (CIBA). Treatment with captopril and sodium restriction in the diet were continued.

Each patient was seen on the same day of the week at the same time of day by the same nurse in the same room, and all blood pressures were measured in the same arm with semiautomatic ultrasound sphygmomanometers (Arteriosonde) with attached recorders. ${ }^{10}$ The measurements were therefore free from observer bias. Supine and standing blood pressures were taken to be the mean of five readings taken at intervals of one to two minutes. Supine blood pressure was measured before standing blood pressure. Blood pressure during treatment with captopril was measured two hours after the patient had taken the morning dose. Pulse rate was measured with a Cambridge 3048 pulse monitor.

Two 24 hour urinary sodium, potassium, and creatinine excretions and volumes were measured, the mean sodium content of two 24 hour urine collections being taken as the urinary sodium excretion. Patients were given careful verbal and printed instructions on how to collect urine over 24 hours. Blood was taken for measurements of concentrations of electrolytes, urea, creatinine, urate, calcium, phosphate, total protein, albumin, and glucose as well as for haemoglobin concentration and packed cell volume. Plasma renin and aldosterone concentrations were measured by radioimmunoassay. All blood samples were taken without stasis after the patient had sat upright for 10 minutes between 9 am and 12 noon. Mean arterial pressure was calculated by adding one third of the pulse pressure to the diastolic pressure. All results are reported as means (SEM). Statistical analysis was performed by paired Student's $t$ test and correlation analysis with the University of London computer and the North Western Universities' statistical package for social sciences.

\section{Results}

The table shows the changes in blood pressure, renin activity, other blood and urinary measurements, and weight during the study. Figure 1 summarises the changes in blood pressure and urinary sodium excretion.

Figure 2 shows the difference between the blood pressures of subjects in their fourth week of taking Slow Sodium tablets and that in their fourth week of taking placebo. Thirteen patients showed a decrease in blood pressure, one patient showed no change, and one patient had a slight

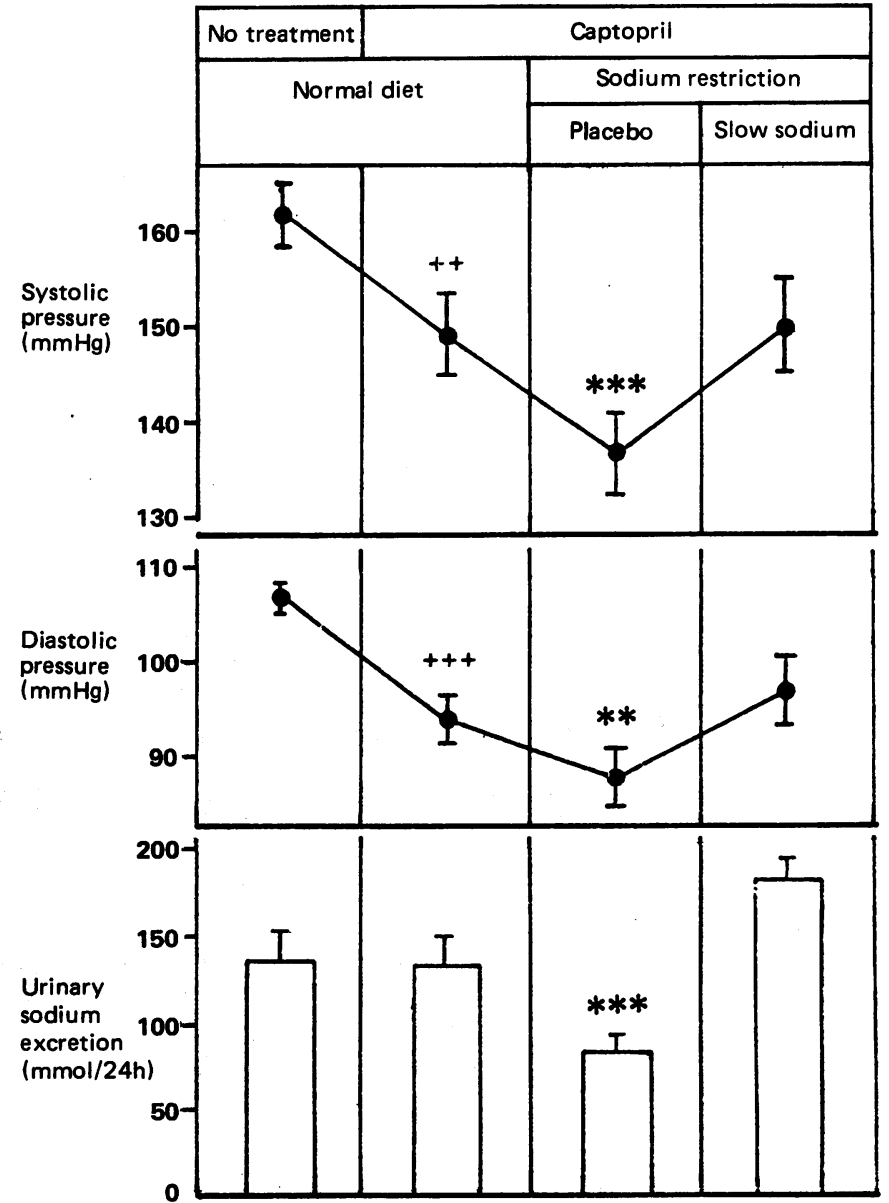

FIG 1-Average supine systolic and diastolic blood pressure and urinary sodium excretion after one month's observation and no treatment; after one month's treatment with captopril $50 \mathrm{mg}$ twice daily; and at end of each month of randomised crossover trial of Slow Sodium tablets $v$ matching placebo. During crossover trial patients moderately restricted sodium intake. $\star \star x p 0.01$, $\star \star \star p<0.001$ comparing measurements on Slow Sodium with placebo. $++\mathrm{p}<0.01,+++\mathrm{p}<0.001$ comparing no treatment with captopril alone.

increase. The table shows the standing blood pressures measured during the study. The difference in blood pressure between the Slow Sodium and placebo periods was not affected by the order in which the tablets were given. There was no significant difference between the responses of men and women or black subjects and white subjects, but the numbers in these subgroups were small.

The difference between mean supine blood pressure in the fourth week of

Changes in blood pressure, renin activity, other blood and urinary measurements, and weight during study. Values are means (SEM)

\begin{tabular}{|c|c|c|c|c|c|c|}
\hline & \multicolumn{3}{|c|}{ Normal diet } & \multicolumn{3}{|c|}{ Sodium restriction } \\
\hline & No treatment & $\begin{array}{c}\text { Treatment with } \\
\text { captopril (4th week) }\end{array}$ & Significance & $\begin{array}{c}\text { Placebo+ } \\
\text { captopril (4th week) }\end{array}$ & $\begin{array}{c}\text { Slow Sodium }+ \\
\text { captopril (4th week) }\end{array}$ & Significance \\
\hline \multicolumn{7}{|l|}{ Blood pressure $(\mathrm{mm} \mathrm{Hg})$ : } \\
\hline Supine & $162 / 107(3 / 2)$ & $149 / 94(5 / 3)$ & $\left\{\begin{array}{l}\text { Systolic } \mathrm{p}<0.01 \\
\text { Diastolic } \mathrm{p}<0.001\end{array}\right.$ & $137 / 88(5 / 3)$ & $150 / 97(54)$ & $\left\{\begin{array}{l}\text { Systolic } p<0.001 \\
\text { Diastolic } p<0.01\end{array}\right.$ \\
\hline Standing & $163 / 116(4 / 2)$ & $148 / 102(4 / 3)$ & $\left\{\begin{array}{l}\text { Systolic } \mathrm{p}<0.01 \\
\text { Diastolic } \mathrm{p}<0.001\end{array}\right.$ & $136 / 96(4 / 3)$ & $149 / 104(4 / 4)$ & $\left\{\begin{array}{l}\text { Systolic } \mathrm{p}<0.001 \\
\text { Diastolic } \mathrm{p}<0.001\end{array}\right.$ \\
\hline $\begin{array}{l}\text { Plasma renin } \\
\text { activity }(\mathrm{nmol} / / \mathrm{h})\end{array}$ & $1 \cdot 28(0.38)$ & $6 \cdot 09(2 \cdot 19)$ & $p<0.05$ & $6.17(1.89)$ & $4 \cdot 32(1.47)$ & $p<0.05$ \\
\hline $\begin{array}{l}\text { Plasma concentrations of: } \\
\text { Aldosterone }(\mathrm{pmol} / \mathrm{l})\end{array}$ & & & & & & \\
\hline $\begin{array}{l}\text { Aldosterone }(\mathrm{pmol} / \mathrm{l}) \\
\text { Sodium }(\mathrm{mmol}(\mathrm{mEq}) / \mathrm{l})\end{array}$ & $\begin{array}{c}424(42) \\
139.7(0.5)\end{array}$ & $\begin{array}{c}283(50) \\
139 \cdot 3(0.6)\end{array}$ & $\begin{array}{l}\mathrm{p}<0 \cdot 01 \\
\text { NS }\end{array}$ & $\begin{array}{c}269(52) \\
139 \cdot 5(0 \cdot 6)\end{array}$ & $\begin{array}{c}244(44) \\
139 \cdot 0(0 \cdot 4)\end{array}$ & $\begin{array}{c}\mathrm{p}<0 \cdot 05 \\
\text { NS }\end{array}$ \\
\hline Potassium $(\mathrm{mmol}(\mathrm{mEq}) / \mathrm{l})$ & $3.9(0 \cdot 1)$ & $3 \cdot 8(0 \cdot 1)$ & NS & $3.9(0 \cdot 1)$ & $3.9(0.1)$ & NS \\
\hline Creatinine $(\mu \mathrm{mo} / /)$ & $94 \cdot 4(6 \cdot 0)$ & $101 \cdot 0(7 \cdot 3)$ & NS & $103.7(6.7)$ & $91 \cdot 2(8 \cdot 1)$ & NS \\
\hline Urate $(\mu \mathrm{mo} / / \mathrm{l})$ & $353(34)$ & $371(20)$ & NS & $371(20)$ & $344(18)$ & NS \\
\hline Urea (mmol/1) & $5 \cdot 7(0.3)$ & $6.0(0.4)$ & NS & $5 \cdot 6(0 \cdot 3)$ & $5 \cdot 2(0 \cdot 3)$ & NS \\
\hline \multirow{4}{*}{$\begin{array}{l}\text { Urinary excretion of: } \\
\text { Sodium }(\mathrm{mmol}(\mathrm{mEq}) / 24 \mathrm{~h}) \\
\text { Potassium }(\mathrm{mmol}(\mathrm{mEq}) / 24 \mathrm{~h}) \\
\text { Creatinine }(\mathrm{mmol} / 24 \mathrm{~h}) \\
\text { Weight }(\mathrm{kg})\end{array}$} & & & & & & \\
\hline & $135(17)$ & $133(17)$ & NS & $83(10)$ & $183(11)$ & $\mathrm{p}<0.001$ \\
\hline & $\begin{array}{c}69(6) \\
15 \cdot 3(1 \cdot 6)\end{array}$ & $\begin{array}{c}62(6) \\
15 \cdot 3(1 \cdot 5)\end{array}$ & NS & $\begin{array}{c}61(5) \\
13 \cdot 9(1 \cdot 1)\end{array}$ & $\begin{array}{c}66(4) \\
13 \cdot 7(0 \cdot 7)\end{array}$ & $\begin{array}{l}\text { NS } \\
\text { NS }\end{array}$ \\
\hline & $76 \cdot 9(2 \cdot 9)$ & $76 \cdot 3(2 \cdot 8)$ & NS & $74 \cdot 2(2 \cdot 6)$ & $74 \cdot 7(2 \cdot 7)$ & NS \\
\hline
\end{tabular}


receiving Slow Sodium and that in the fourth week of receiving placebo was calculated and related to the variables that had been measured. The decrease in blood pressure correlated significantly with the reduction in urinary sodium excretion $(r=0.52 ; p<0.05)$ (fig 3 ) as well as with the decrease in weight $(r=0.53 ; p<0.05)$ and the increase in plasma albumin concentration $(r=0.52 ; p<0.053)$. There was no significant correlation between patients' blood pressure when they were taking Slow Sodium tablets and the decrease in blood pressure seen during salt restriction, but such an observation may be invalid as the decrease in blood pressure was partly calculated from the blood pressure of patients when they were taking Slow Sodium tablets. ${ }^{11}$ When the mean supine blood pressure of patients taking Slow Sodium tablets was plotted against their equivalent blood pressure when they were taking placebo either on a linear or $\log$ scale $^{12}$ the slope of the line of correlation obtained was not significantly different from the slope of the line of identity, thus confirming that there was no relation between the severity of blood pressure and decrease in blood pressure during salt restriction while taking captopril. All patients completed the trial without adverse effects.

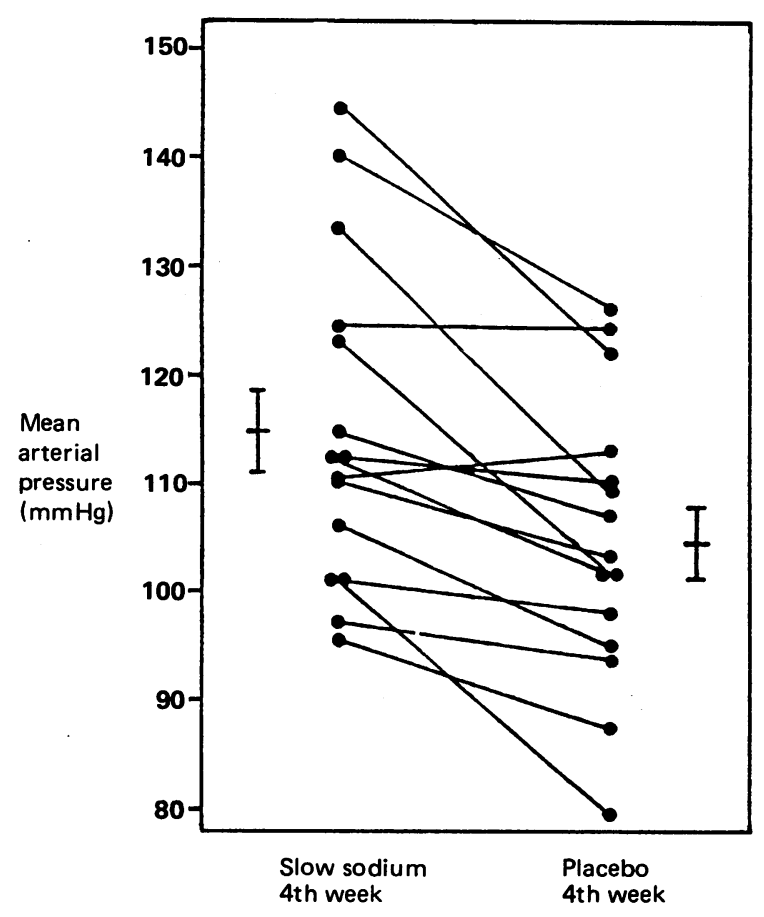

FIG 2-Differences in mean supine blood pressure from fourth week of taking Slow Sodium to fourth week of taking placebo while also taking captopril $50 \mathrm{mg}$ twice daily $(\mathrm{p}<0.001)$ and moderately restricting sodium intake. (Average supine blood pressure (SEM) is also shown and fell by $9 \cdot 1 \%$.)

\section{Discussion}

The results of this double blind randomised crossover study show that in patients who have essential hypertension and who are already receiving treatment with an angiotensin converting enzyme inhibitor a moderate reduction in sodium intake causes a further decrease in blood pressure. The decrease seen in this study was greater than that seen in a similar double blind study of sodium restriction alone, in which the patients were not receiving drugs. ${ }^{13}$ Two other studies of moderate sodium restriction in patients who were not taking drugs that decreased blood pressure found that salt restriction alone had a smaller effect; New Zealand workers found a decrease in blood pressure that just failed to reach significance, ${ }^{14}$ and Watt $e$ al performed a double blind trial with a similar protocol to our own that showed that sodium restriction had no effect on blood pressure. ${ }^{15}$ In the study of Watt $e t$ al, however, when patients were receiving their "normal" sodium intake-that is, Slow Sodium tablets-the mean supine blood pressure was in the normal range, at $136 / 83 \mathrm{~mm} \mathrm{Hg}$. 15

When most studies of dietary salt restriction alone are considered the blood pressure of people with milder hypertension is less affected by salt restriction, ${ }^{2}$ and normotensive subjects show little or no decrease in blood pressure. ${ }^{2}$ This seems to be related to a greater increase in renin activity and angiotensin II concentration in people with lower initial blood pressure, which offsets the decrease in blood pressure that would have occurred during salt restriction. ${ }^{35} \mathrm{~A}$ converting enzyme inhibitor, by reducing the

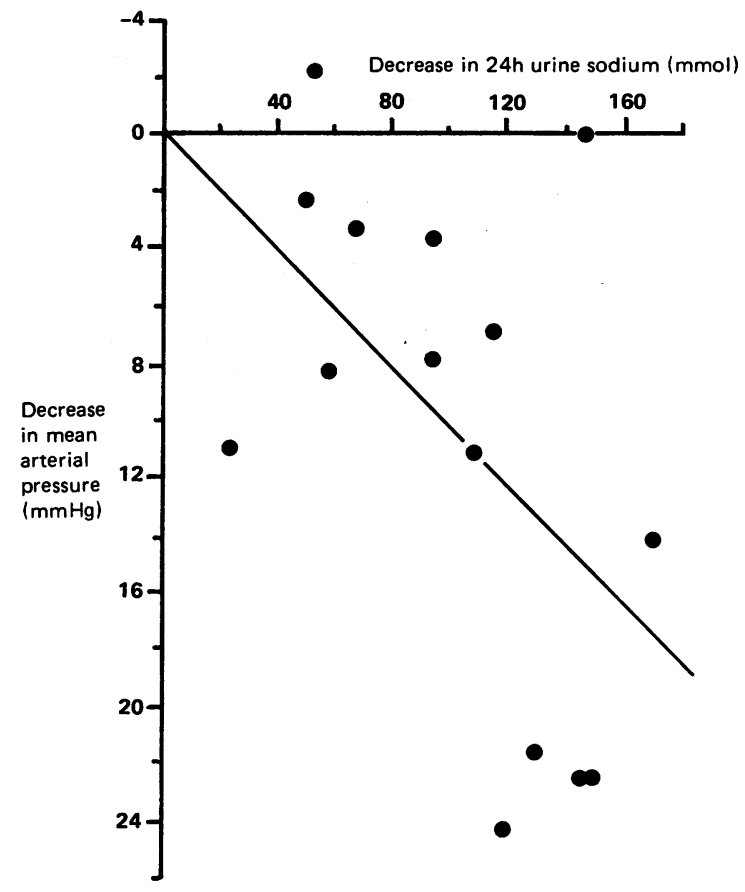

FIG 3-Reduction in 24 hour urinary sodium from fourth week of treatment with Slow Sodium to fourth week of treatment with placebo against decrease in mean supine arterial pressure $(r=0.52 ; p<0.05)$.

formation of angiotensin II in spite of the increased renin activity, blocks this compensatory response so that blood pressure is much more dependent on changes in sodium and water balance. This concept is supported by the finding in our study that the decrease in blood pressure when sodium intake was reduced was directly related to the reduction in urinary sodium excretion and to the weight loss and increase in plasma albumin concentration that occurred. The lack of relation between the severity of the blood pressure and the decrease in blood pressure in our study suggests that once the renin system is blocked sodium restriction is then effective, even in patients with milder or borderline hypertension.

Angiotensin converting enzyme inhibitors alone do not usually control blood pressure, particularly in patients with more moderate hypertension. The addition of a diuretic has been advocated and shown to have an additive effect. ${ }^{16} 17$ The metabolic effects of thiazide diuretics also seem to be lessened by the addition of a converting enzyme inhibitor. ${ }^{17}$ Nevertheless, even in this latter study when Weinberger combined treatment of a diuretic and captopril there was still a significant decrease in plasma potassium concentration and an increase in urate concentration. ${ }^{17} \mathrm{We}$ did not compare directly the effectiveness of moderate salt restriction and captopril against that of a thiazide diuretic and captopril. The decrease in blood pressure with salt restriction in our study, however, seems to be similar to that found when a diuretic has been added to captopril. ${ }^{16} 17$ An important advantage of salt restriction over diuretics is that moderate salt restriction causes few or no metabolic side effects, in particular no decrease in plasma potassium concentration.

Compliance with long term moderate sodium restriction could be a problem in the widespread use of combined treatment of moderate salt restriction and converting enzyme inhibitors. Our own experience in patients who have now restricted moderately their salt intake for some years-that is, reduced it to about $80 \mathrm{mmol} / \mathrm{day}$ - has 
shown that they have little difficulty in sticking to this sort of diet provided that they eat at home, a finding similar to that of Thaler $e t$ $a l$ in New Zealand.$^{18}$ Long term compliance is helped by the fact that once patients have overcome the first few weeks of the change in the diet, in which food may taste bland, salt sensitivity of the taste receptors in the mouth changes. ${ }^{19}$ Most patients then find that the foods with a high salt content that they used to like are unpleasant and much prefer foods with less salt. Our results also suggest that once the formation of angiotensin II is blocked more severe sodium restriction would be even more effective in decreasing blood pressure. For patients to reduce sodium intake below $80 \mathrm{mmol} /$ day, however, requires the provision of special foods, particularly salt free bread, that are not yet generally available in the United Kingdom and the avoidance of most processed foods.

We think that in patients with mild to moderate essential hypertension who are prepared moderately to reduce their sodium intake such a reduction, together with other non-pharmacological advice, should be the first step in their management. If this fails to control their blood pressure additional treatment with an angiotensin converting enzyme inhibitor such as captopril is particularly effective. This approach overcomes the objections of lack of efficacy that have been made both against moderate salt restriction alone and converting enzyme inhibition alone.

\section{References}

1 Brown JJ, Lever AF, Robertson JIS, Semple PF. Should dietary sodium be reduced? The sceptics' position. Qf Med 1984;212:427-37.

$2 \mathrm{MacGregor} \mathrm{GA.} \mathrm{Sodium} \mathrm{is} \mathrm{more} \mathrm{important} \mathrm{than} \mathrm{calcium} \mathrm{in} \mathrm{essential} \mathrm{hypertension.} \mathrm{Hypertension}$ 1985;7:628-37.
3 Longworth DL, Drayer JIM, Lieber MA, Laragh JH. Divergent blood pressure responses during short-term sodium restriction in hypertension. Clin Pharmacol Ther 1980;27:544-6.

4 MacGregor GA, Markandu ND, Sagnella GA. Dietary sodium restriction in normotensive subjects and patients with essential hypertension. Clin Sci 1982;63(suppl):399-402S.

5 Cappuccio FP, Markandu ND, Sagnella GA, MacGregor GA. Sodium restriction lowers high blood pressure through a decreased response of the renin system-direct evidence using saralasin. $f$ Hypertension 1985;3:243-7.

6 Ondetti MA, Rubin B, Cushman DW. Design of specific inhibitors of angiotensin-converting enzyme: new class of orally active antihypertensive agents. Science 1977;196:441-4.

7 Hofbauer KG, Fuhrer W, Heusser Ch, Wood JM. Comparison of different drug interference with the renin-angiotensin system. $\mathcal{F}$ Cardiovasc Pharmacol 1985;7(suppl):62-8S.

8 Case DB, Atlas SA, Laragh JH. Position paper: physiologic effects and diagnostic relevance of acute converting enzyme blockade. In: Laragh JH, Buhler FR, Seldin DW, eds. Frontiers in hypertension research. New York: Springer-Verlag, 1981:541-50.

9 MacGregor GA, Markandu ND, Roulston JE, Jones JC. Essential hypertension: effect of an oral inhibitor of angiotensin-converting enzyme. Br Med $\mathcal{J} 1979 ;$;ii:1106-9.

10 George CF, Lewis PJ, Petrie A. Clinical experience with use of ultrasound sphygmomanometer. BrHeart f 1975;37:804-7.

11 Gill JS, Zezulka AV, Beevers DG, Davies P. Relation between initial blood pressure and its fall with treatment. Lancet 1985; ;:567-9.

12 MacGregor GA, Sagnella GA, Macrae KD. Misleading paper about misleading statistics. Lancet 1985;i:926-7.

13 MacGregor GA, Markandu ND, Best FE, et al. Double-blind randomised crossover trial of moderate sodium restriction in essential hypertension. Lancet 1982;i:351-5.

14 Richards AM, Espiner EA, Maslowski AH, et al. Blood pressure response to moderate sodium restriction and potassium supplementation in mild essential hypertension. Lancet 1984; $\mathrm{i}$ : restriction $757-61$.

15 Watt GCM, Edwards C, Hart JT, Hart M, Walton P, Foy CJW. Dietary sodium restriction for mild hypertension in general practice. BrMed f 1983;286:432-6.

16 MacGregor GA, Markandu ND, Banks RA, Bayliss J, Roulston JE, Jones JC. Captopril in essential hypertension; contrasting effects of adding hydrochlorothiazide or propranolol. BrMed f 1982;284:693-6.

17 Weinberger $\mathrm{MH}$. Blood pressure and metabolic responses to hydrochlorothiazide, captopril, and the combination in black and white mild-to-moderate hypertensive patients. $\mathcal{f}$ Cardiovasc Pharmacol 1985;7(suppl):52-5S.

18 Thaler BI, Paulin JM, Phelan EL, Simpson FO. A pilot study to test the feasibility of salt restriction in a community. $N Z$ Med $\mathcal{F} 1982 ; 95: 839-42$.

19 Beauchamp GK, Bertino M, Engelman K. Modification of salt taste. Ann Intern Med 1983;98: 763-9.

(Accepted 30 October 1986)

\title{
Are we drinking our neurones away?
}

\author{
CLIVE HARPER, JILLIAN KRIL, JOHN DALY
}

\begin{abstract}
A quantitative neuropathological necropsy study of the human cerebral cortex showed that the number of cortical neurones in the superior frontal cortex in chronic alcoholic patients is significantly reduced compared with that in controls matched for age and sex. The number of neurones in the motor cortex did not differ significantly between the controls and alcoholics, but in both cortical regions there was evidence that alcoholic patients had smaller (shrunken) neurones than controls.

Further studies are necessary to identify other regions of the cerebral cortex that are selectively damaged in brain damage associated with alcohol.
\end{abstract}

\footnotetext{
Department of Pathology, University of Sydney, and Royal Prince Alfred Hospital, Sydney, Australia

CLIVE HARPER, MB, FRCPA, professor of neuropathology

Department of Pathology, University of Sydney

JILLIAN KRIL, BSC, research assistant
}

Department of Neuropathology, Royal Perth Hospital

JOHN DALY, BSC, research assistant

Correspondence to: Professor C Harper, Department of Pathology, University of Sydney, Sydney 2006, Australia.

\section{Introduction}

Alcoholic beverages have been available in almost every civilisation known to man. Today, particularly in Western countries, they are an accepted part of society.

The popular belief that excessive alcohol (ethanol) intake, particularly "binge" drinking, causes damage to nerve cells and death in the cerebral cortex is not based on any reliable scientific data. Pathologists have commented on a "patchy loss of cortical neurones" in the brains of alcoholic patients, ${ }^{1}$ but this has not been quantified, and similar subjective observations in other diseases have often been shown to be invalid. There are experimental data, however, that show a loss of neurones in animal models of chronic alcohol intoxication. ${ }^{2}$ In a recent collaborative study we documented the loss of neurones in the cerebellar vermis of alcoholics. ${ }^{3}$

With regard to the cerebral cortex neuroradiological evidence shows that chronic alcoholic patients ${ }^{4}$ and even heavy social drinkers s suffer from brain "shrinkage," and there is some correlation between this change and clinical and neuropsychological deficiencies. In recent quantitative neuropathological studies we have shown that the weights of the brains of chronic alcoholics are significantly reduced ${ }^{6}$ and that the pericerebral space (the space between the brain and the skull) is increased. ' Stereometric measurements of the volumes of cortical grey matter, white matter, and basal ganglia in the brains of controls and alcoholics have shown that the loss of cerebral tissue in alcoholics is largely from the white matter. ${ }^{8}$ This shrinkage of white matter could be caused by loss of neurones with subsequent degeneration of axons. The purpose of this study was to investigate such a hypothesis. 